\title{
Effect of Employee demographic Characteristics and family/work conflict on organisational commitment among Police officers in Nakuru County, Kenya
}

\author{
Esther Lekaram ${ }^{1}$, Dr. Dinah J. Kipkebut ${ }^{2}$, \\ ${ }^{1}$ Egerton University \\ ${ }^{2}$ Senior Lecturer, Egerton University
}

\begin{abstract}
This paper examines the demographic characteristics and related variables on family/work conflict among the Police Officers in Nakuru County, Kenya. The participants were from eight (8) Police Division and a simple random sample of 170 was derived from a total number of 278 Officers. The level of conflict that employees perceive between their working and personal lives on organizational commitment was based on their personal characteristics which included: gender, marital status, age, level of education, tenure and number of hours worked among the police officers. The report suggested that the biographical personal characteristics suggested that those who participated there were more male officers compared to the female gender. The results showed that more female police officers experienced more stress than men which spill into their work due to the multiple roles they play as wives, mothers, care givers, family career as well as employees. The results are discussed in terms of marital status, level of education, tenure of service and numbers of hours worked per day on how they influence organizational commitment among the police officers in Nakuru County, Kenya.
\end{abstract}

Key Words: Demographic characteristics; Family-work conflict; Organizational Commitment; Police Officers.

\subsection{Back ground of the Study}

As many organizations strive to understanding the challenges of attracting and retaining the best talent, coupled with the rising issue of work life conflicts, it is vital that managers employ a number of approved human resource (HR) practices in order to attain organizational goals (McClean \& Collins, 2011). Subsequently, managers are now undertaking proven, Work Life Initiatives (WLI) that minimize costs, reliant motivators, competitive motivators, resource makers and commitment maximization appropriate to improve employee's commitment, do enhance employee satisfaction and performance (Boxall et al., 2011).

The definition of Work life conflict based on two studies; Edwards and Rothbard, 2000 and Greenhaus and Beutell, 1985, is as a 'form of inter-role conflict in which work and family demands are mutually incompatible so that meeting demands in one domain makes it difficult to meet demands in the other'. When work and family are in conflict, attaining rewards in one domain requires trading off rewards in the other domain (Edwards \& Rothbard, 2000).

Some of the studies on work-family conflict have focused on construct measurement, involving the measurement of the direction and process of interaction between work roles and family roles as found by Kossek, (2016) and Allen et al. (2000) that argued 'differential finding across studies in the relationship between work-family conflict and life satisfaction suggests that undetected moderator variables may be involved'. A research project by Kopelman et al. (1983) developed a four-item scale and then expanded it to an eight-item scale that measured work-to-family conflict with such items as "My work schedule often 
conflicts with my family life." Therefore, work life can be conceptualised to consist of two key components namely; practical aspects related with time crunches and scheduling conflicts and the perceptual aspect of feeling overwhelmed, burdened and stressed by the pressures of the multiple task and roles (Higgins et al., 2001). Therefore, this study addressed the impact of employee demographic characteristics and family/work conflict on organizational commitment; among the police officers in Nakuru County, Kenya.

\section{Literature Review}

\section{Work/Family Conflict among the police officers}

Work family role conflicts and family to work role emerges when the time used to satisfy the prerequisites of one role makes it hard to satisfy the necessities of another role (Greenhaus \& Beutell, 1985). Most researches have observed work family conflict as a dimensional construct in spite of the fact that it provides suggestions that work affected family and family affected work, which brought in the element of the bidirectional relationship (Frone et al., 1992; Sutton, 2000).

This would try to apprehend the causes and consequences of the construct that carry on across time and culture in order to help employees thwart and handle the discomfort that arises when work and family demands clash. Duxbury \& Higgins, (2003) in their study found out that, an individual is entitled to different roles in the span of his/her life; roles from work and non-work. Work/family conflict exists when time and energy demands to fulfil one role thus making it difficult to partake other role. Work family conflict is defined as "push and pull" between family and work (Lockwood, 2003). Making the concern of this study to look in which ways the police officers faces these challenges both at work and at their private life, which affects organizational commitment in line of their duty.

Netemeyer et al., (1996) in their research defined 'work conflict' in two facets. One, as a 'form of inter-role conflict occurring due to general demands and strain created by the job interfering with ones' ability to perform family related responsibilities'. These family related responsibilities could be extensive to other roles such as community service, cultural and religious participation and social interaction where individual's leisure time is considered. Secondly, as 'a role conflict' resulting from general needs and strain created by the family interfering with employee's ability to perform their duties/tasks at work.

The two aspects when put together they become an antecedent of work life conflict construct. WFC/FWC is hypothesised to consist of the three components namely time conflicts role produced strain and incompatible in role behaviour patterns (Greenhaus \& Beutell, 1985). It predicts that a person's expectations are surrounded in each of the different roles he/she performs and can generate inter-role conflict. According to Kahn et al. (1964), the inter-role conflict come about because it is difficult for the focal person to meet all expectations of his or her work and family duties since each role requires time, energy and commitment.

\section{Organizational Commitment among the police officer}

Stated by Cohen (2003), 'organizational commitment is a force that binds an individual to a course of action of relevance to one or more targets'. Bashir and Ramay (2008) also added that organizational commitment is a state in which an employee aligns to a particular organization and its goals and aspires to maintain membership in the organization. Organizational commitment is one of the most powerful factors that determine organization's performance (Manmohan, 2013). The National Police Service Commission have goals to be achieved and must have committed workers who are capable of overcoming work family role conflict. Organizational commitment has been defined as 'the strength of an individual's identification and involvement with a particular organization" (Eaton, 2003). It is conceptualized that it has three elements; a belief in and recognition of goals and values, a willingness to put forth effort, and a strong aspiration to maintain membership. Behson (2002), 'commitment is a disposition to engage in consistent lines of activity because of the accumulation of earnings that would be lost if the activity were discontinued'. Allen and Meyer (1990) explained commitment in three different aspects. The 'affective commitment as the extent of an employee's emotional attachment, identification with, and involvement in the organization, the continuance commitment as a judgment of costs related with leaving the organization and the normative 
commitment as the degree to which an employee believes some sense of obligation to stay with the organization'.

\section{Statement of the Study}

Work and family life balance have meaning to the employee. Work has financial benefits and can offer job satisfaction which occurs when there is a fit between employees' personal values and work goals (Lockwood, 2003). Family life is crucial to people since they are able to relate with their families hence giving them a sense of belonging and an urge to work even harder. However, despite the significance of work, family roles and organizational commitment, police officers are faced with difficulties in trying to balance between work and family life because of the nature of their work which results to work/family conflict. Police service is one of the most critical and risky professions in the world (Oweke et al, 2014). Omeja and Githigaro (2010) concluded that Kenyan police officers were exposed to distressing and violent work environment as they are in endless confrontation with drug and alcohol addicts, violent law-breakers and political hooliganism during party electioneering. They also have to deal with constant terror threats, robberies, and destruction of properties, hijacking, carjacking, fraud and dealing with organized gangsters among other crimes. Similarly, Ongoro \& Oloko (2015) reported that Kenyan police officers continually face the effects of murder, violence, accidents, disasters, rotating shifts, long hours and exposure to life's tragedies which have had a heavy toll on police officers and their families.

Police Officers are also faced with the problem of acquiring basic needs, living in deplorable conditions, inadequate working tools such as patrol vehicles, lack of motivation and compensation for overtime, poor salaries, frequent transfers which distant them with their families, work overload due to inadequate staff and inability to socialize due to lack of time (Gul, 2000). The consequences of the challenges that police officers face include an alarming resulting in high divorce rates, suicide, domestic violence, heart attacks, cancer, depression and alcoholism (Ongoro \& Oloko, 2015). Various studies that have been done on work/family conflict have been done on correctional officers and nurses in Western countries where working conditions are considerably better with limited studies done in Africa and Kenya in particular. The study therefore seeks to examine the effect of demographic characteristics and work/family conflict on organizational commitment among police officers in Nakuru County, Kenya.

From the above reviewed literature, the following hypotheses are proposed:

$\mathrm{H}_{0} 1$ : There are no significant differences in family/work conflict and organisational commitment based on employee personal characteristics namely: gender, marital status, age, education, tenure and number of hours worked.

$\mathrm{H}_{0} 2$ : Family/work conflict (time-based) does not have statistically significant effect on organisational commitment of Police officers at Nakuru County

$\mathrm{H}_{0} 3$ : Family/work conflict (strain-based) does not have statistically significant effect on organisational commitment of Police officers at Nakuru County

$\mathrm{H}_{0} 4$ : Family/work conflict (behaviour-based) does not have statistically significant effect on organisational commitment of Police officers at Nakuru County

$\mathrm{H}_{0} 5$ : The combined effect of employee personal characteristics and family/work conflict (time-based, strainbased and behaviour-based) do not have statistically significant effect on organisational commitment among Police officers at Nakuru County

\section{Method}

The study adopted a descriptive research design. There are nine (9) police divisions in Nakuru County. Simple random sampling, using the lottery method, was used to select eight (8) police divisions in Nakuru County, Kenya, while the remaining one (1) police division was used in the pilot study. The population of the study was 973 Police officers. Using table by Krejcie and Morgan (1970) for determining sample size, a sample of 278 police officers was derived. Proportionate random sampling was used to determine the sample size per police division and thereafter simple random sampling was used to select the respondents from each of the police division. Questionnaires were physically distributed and then picked. A total of 170 questionnaires were successfully filled and collected, giving a response rate of $61 \%$ which, according to 
Mugenda \& Mugenda 2003) is good. The respondents' biographical personal characteristics is can be observed in Table 1 presented below.

Table 1: Summary of Personal characteristics of the police officers

\begin{tabular}{|l|l|l|}
\hline Variables & Frequency & Percent (\%) \\
\hline Gender & 121 & \\
Male & 49 & 71.2 \\
Female & 170 & 28.8 \\
\hline & & 100 \\
\hline Age & 21 & \\
Below 25 years & 100 & 12.4 \\
25 - 34 years & 25 & 58.8 \\
$35-44$ years & 24 & 14.7 \\
45 years and above & 170 & 14.1 \\
\hline & & 100 \\
\hline Marital status & 33 & \\
Single & 137 & 19.4 \\
Married & 170 & 80.6 \\
\hline & & 100 \\
& & \\
\hline Level of education & 105 & \\
Secondary school & 20 & 61.8 \\
Certificate level & 20 & 11.8 \\
Diploma & 25 & 11.8 \\
Bachelors degree & 170 & 14.6 \\
\hline & & 100 \\
\hline Tenure & 34 & 20.0 \\
Below 5 years & 69 & 40.6 \\
6 - 10 years & 43 & 25.3 \\
11 - 15 years & 24 & 14.1 \\
\hline 16 years and above & 170 & 100 \\
\hline & & 39.4 \\
\hline Hours worked & 27 & 100 \\
8 hours & 76 & \\
$9-13$ hours & 67 & \\
14 hours and above & 170 & \\
\hline & & \\
\hline
\end{tabular}

\section{Measurement of variables}

Based on an extensive review of the literature, a questionnaire consisting of 37 items was developed to capture aspects of police officers personal characteristics, perceptions on family/work conflict (time-based, strain-based and behaviour-based) and organisational commitment. The questionnaire consisted of three (3) sections. Section A consisted of 6 questions that aimed to derive personal information about the Police officers namely, age, gender, marital status, level of education, years worked and number of hours worked per day. Items in Sections B and C were measured on a 5-point likert scale from $1=$ Strongly agree to $5=$ Strongly disagree. Cronbach reliability coefficients were then computed for each variable and the results showed acceptable reliability of 0.70 (Saunders, Lewis and Thornhill, 2009).

Family/work Conflict: Section B consisted of 15 items on Police officers perception of family/work conflict and these items were developed by Carlson, Kacmar \& Williams (2000). Family/work conflict (time-based) had five (5) items which included 'The time I spend with my family often causes me to not 
spend time in activities at work that could be helpful to my career'. The Cronbach's alpha of the five items was $\alpha=0.758$. Family/work conflict (strain-based) had five (5) items which included 'Due to all the pressures at home, sometimes it is hard for me to do my job well'. The Cronbach alpha of the five items was $\alpha=0.810$. Family/work conflict (Behaviour-based) had five (5) items which included 'Behaviour that is effective and necessary for me at home would be counterproductive at work'. The Cronbach alpha of the five items was $\alpha=0.710$.

Organisational commitment: Finally, Section C had items that measured Police officers organisational commitment. These items were adopted from the scale developed by Allen and Meyer (1990) on affective, normative and continuance commitment which included 'I do feel like part of a family at the Police service' (Affective commitment), 'I am concerned about what might happen if I left the Police service without having another position lined up' (Continuance commitment) and 'Even if it was to my advantage, I do not feel that it would be right to leave the Police service now' (Normative commitment). The Cronbach alpha of the 16 items was $\alpha=0.895$.

\subsection{RESULTS}

The testing of hypotheses was subjected to statistical analysis as shown below. Independent samples t-tests and one-way Analysis of Variance (ANOVA) was carried out to test Hypothesis One. Pearson Correlation analysis was carried out to test Hypothesis Two to Four. Finally, multiple regression analysis was conducted to test Hypothesis Five.

\section{Results of Independent samples t-tests and one-way Analysis of Variance (ANOVA)}

$H_{0}$ 1: There are no significant differences in family/work conflict and organisational commitment based on employee personal characteristics namely: gender, marital status, age, education, tenure and number of hours worked.

\section{a) Gender}

Table 2: Results of Independent Samples t-test exploring differences in family/work conflict and organisational commitment based on gender

\begin{tabular}{|c|c|c|c|c|c|c|}
\hline Variables & Gender & $\mathrm{N}$ & Mean & $\begin{array}{l}\text { Std. } \\
\text { Deviation }\end{array}$ & $\begin{array}{l}t- \\
\text { value }\end{array}$ & Sig. \\
\hline Family/work conflict (Time based) & $\begin{array}{l}\text { Male } \\
\text { Female }\end{array}$ & $\begin{array}{l}121 \\
49\end{array}$ & $\begin{array}{l}19.83 \\
19.45\end{array}$ & $\begin{array}{l}3.36 \\
3.51\end{array}$ & .654 & .514 \\
\hline Family/work conflict (Strain based) & $\begin{array}{l}\text { Male } \\
\text { Female }\end{array}$ & $\begin{array}{l}121 \\
49 \\
\end{array}$ & $\begin{array}{l}15.58 \\
19.04 \\
\end{array}$ & $\begin{array}{l}4.50 \\
3.05 \\
\end{array}$ & -4.942 & .000 \\
\hline Family/work conflict (Behaviour) & $\begin{array}{l}\text { Male } \\
\text { Female }\end{array}$ & $\begin{array}{l}121 \\
49\end{array}$ & $\begin{array}{l}12.45 \\
12.67\end{array}$ & $\begin{array}{l}4.01 \\
3.69\end{array}$ & -.329 & .742 \\
\hline Organisational commitment & $\begin{array}{l}\text { Male } \\
\text { Female }\end{array}$ & $\begin{array}{l}121 \\
49\end{array}$ & $\begin{array}{l}55.07 \\
55.65\end{array}$ & $\begin{array}{l}12.22 \\
7.09\end{array}$ & -.311 & .756 \\
\hline
\end{tabular}

The results in Table 2 show that there were no statistically significant differences in the mean scores of family/work conflict (time-based and behaviour-based) and organisational commitment among male and female respondents $(p>0.05)$. However, the results show that there was gender difference in the mean scores of strain-based family/work conflict $(t=-4.942, \mathrm{p}=0.000)$ with female respondents having significantly higher mean scores $(M=19.04)$ than male respondents $(M=15.58)$. It is possible that female police officers experience more stress than men which spill into their work due to the multiple roles they play as wives, mothers, family carer as well as employees. 


\section{b) Marital status}

Table 3: Results of Independent Samples t-test exploring differences in family/work conflict and organisational commitment based on marital status

\begin{tabular}{|l|l|l|l|l|l|l|}
\hline \multirow{2}{*}{ Marital Status } & & $\mathrm{N}$ & Mean & $\begin{array}{l}\text { Std. } \\
\text { Deviation }\end{array}$ & $\begin{array}{l}t \text { - } \\
\text { value }\end{array}$ & Sig. \\
\hline Family/work conflict (Time based) & Single & 33 & 20.52 & 2.11 & 1.506 & .134 \\
& Married & 137 & 19.53 & 3.62 & & \\
\hline Family/work conflict (Strain based) & Single & 33 & 17.82 & 4.09 & 1.812 & .072 \\
& Married & 137 & 16.28 & 4.45 & & \\
\hline Family/work conflict (Behaviour) & Single & 33 & 12.52 & 3.53 & -.004 & .997 \\
& Married & 137 & 12.52 & 4.01 & & \\
\hline Organisational commitment & Single & 33 & 52.42 & 8.70 & -1.651 & .101 \\
& Married & 137 & 55.92 & 11.37 & & \\
\hline
\end{tabular}

The results in Table 3 show that there were no statistically significant differences in the mean scores of family/work conflict (time-based, strain-based and behaviour-based) and organisational commitment among single and married respondents $(p>0.05)$.

c) Age

Table 4: Results of ANOVA exploring differences in family/work conflict and organisational commitment based on age

\begin{tabular}{|c|c|c|c|c|c|c|}
\hline & & $\mathrm{N}$ & Mean & $\begin{array}{l}\text { Std. } \\
\text { Deviation }\end{array}$ & & \\
\hline $\begin{array}{l}\text { Family/Work } \\
\text { (Time based) }\end{array}$ & $\begin{array}{l}\text { Below } 25 \text { years } \\
25-34 \text { years } \\
35-44 \text { years } \\
45 \text { years and } \\
\text { above }\end{array}$ & $\begin{array}{l}21 \\
100 \\
25 \\
24\end{array}$ & $\begin{array}{l}9.81 \\
10.34 \\
10.60 \\
10.13\end{array}$ & $\begin{array}{l}1.17 \\
3.86 \\
3.30 \\
2.80\end{array}$ & .232 & .874 \\
\hline $\begin{array}{l}\text { Family/work conflict } \\
\text { (Strain based) }\end{array}$ & $\begin{array}{l}\text { Below } 25 \text { years } \\
25-34 \text { years } \\
35 \text { - } 44 \text { years } \\
45 \text { years and } \\
\text { above }\end{array}$ & $\begin{array}{l}21 \\
100 \\
25 \\
24\end{array}$ & $\begin{array}{l}11.33 \\
14.03 \\
13.92 \\
12.21\end{array}$ & $\begin{array}{l}3.43 \\
4.71 \\
4.55 \\
2.93\end{array}$ & 3.014 & .032 \\
\hline $\begin{array}{l}\text { Family/work conflict } \\
\text { (Behaviour based) }\end{array}$ & $\begin{array}{l}\text { Below } 25 \text { years } \\
25-34 \text { years } \\
35-44 \text { years } \\
45 \text { years and } \\
\text { above }\end{array}$ & $\begin{array}{l}21 \\
100 \\
25 \\
24\end{array}$ & $\begin{array}{l}17.33 \\
17.74 \\
16.92 \\
17.13\end{array}$ & $\begin{array}{l}3.14 \\
4.17 \\
3.29 \\
4.12\end{array}$ & .389 & .761 \\
\hline $\begin{array}{l}\text { Organisational } \\
\text { commitment }\end{array}$ & $\begin{array}{l}\text { Below } 25 \text { years } \\
25 \text { - } 34 \text { years } \\
35-44 \text { years } \\
45 \text { years and } \\
\text { above }\end{array}$ & $\begin{array}{l}21 \\
100 \\
25 \\
24\end{array}$ & $\begin{array}{l}54.10 \\
56.00 \\
52.68 \\
55.75\end{array}$ & $\begin{array}{l}8.49 \\
11.01 \\
12.52 \\
11.18\end{array}$ & .703 & .551 \\
\hline
\end{tabular}

The results in Table 4 show that there were no statistically significant differences in the mean scores of family/work conflict (time-based and behaviour-based) and organisational commitment based on age of the 
respondents $(p>0.05)$. However, the results show that the mean scores of family/work conflict (strain-based) differed significantly among the four (4) age groups $(F=3.014, \mathrm{p}=0.032)$. Respondents aged $25-34$ years $(\mathrm{M}=14.03)$ and $35-44$ years $(\mathrm{M}=13.92)$ have significantly higher mean scores than respondents aged below 25 years $(M=11.33)$. A possible explanation is that Police officers aged between 25 to 44 years are more likely to be married with young children resulting in problems and demands they face at home spilling over into the workplace. On the other hand, Police officers below 25 years of age were more likely to be single and therefore may not have family-related problems that may interfere with their work.

\section{d) Level of education}

Table 5: Results of ANOVA exploring differences in family/work conflict and organisational commitment based on level of education

\begin{tabular}{|c|c|c|c|c|c|c|}
\hline & & $\mathrm{N}$ & Mean & $\begin{array}{l}\text { Std. } \\
\text { Deviation }\end{array}$ & $\begin{array}{l}F \\
(\text { ANOVA) }\end{array}$ & Sig. \\
\hline $\begin{array}{l}\text { Family/Work conflict } \\
\text { (Time based) }\end{array}$ & $\begin{array}{l}\text { Secondary } \\
\text { School } \\
\text { College } \\
\text { certificate } \\
\text { Diploma } \\
\text { Bachelor's } \\
\text { Degree }\end{array}$ & $\begin{array}{l}105 \\
20 \\
20 \\
25\end{array}$ & $\begin{array}{l}10.84 \\
9.75 \\
9.50 \\
9.00\end{array}$ & $\begin{array}{l}3.63 \\
2.88 \\
2.98 \\
2.65\end{array}$ & 2.716 & .046 \\
\hline $\begin{array}{l}\text { Family/work conflict } \\
\text { (Strain based) }\end{array}$ & $\begin{array}{l}\text { Secondary } \\
\text { School } \\
\text { College } \\
\text { certificate } \\
\text { Diploma } \\
\text { Bachelor's } \\
\text { Degree }\end{array}$ & $\begin{array}{l}105 \\
20 \\
20 \\
25\end{array}$ & $\begin{array}{l}13.81 \\
12.40 \\
12.75 \\
13.16\end{array}$ & $\begin{array}{l}4.33 \\
4.69 \\
4.12 \\
4.82\end{array}$ & .808 & .491 \\
\hline $\begin{array}{l}\text { Family/work conflict } \\
\text { (Behaviour based) }\end{array}$ & $\begin{array}{l}\text { Secondary } \\
\text { School } \\
\text { College } \\
\text { certificate } \\
\text { Diploma } \\
\text { Bachelor's } \\
\text { Degree }\end{array}$ & $\begin{array}{l}105 \\
20 \\
20 \\
25\end{array}$ & $\begin{array}{l}17.75 \\
16.15 \\
18.00 \\
17.00\end{array}$ & $\begin{array}{l}3.72 \\
4.69 \\
3.77 \\
4.12\end{array}$ & 1.186 & .317 \\
\hline $\begin{array}{l}\text { Organisational } \\
\text { commitment }\end{array}$ & $\begin{array}{l}\text { Secondary } \\
\text { School } \\
\text { College } \\
\text { certificate } \\
\text { Diploma } \\
\text { Bachelor's } \\
\text { Degree }\end{array}$ & $\begin{array}{l}105 \\
20 \\
20 \\
25\end{array}$ & $\begin{array}{l}56.19 \\
61.25 \\
49.40 \\
51.12\end{array}$ & $\begin{array}{l}10.31 \\
6.93 \\
12.17 \\
12.31\end{array}$ & 5.780 & .001 \\
\hline
\end{tabular}

The results in Table 4 show that there were no statistically significant differences in the mean scores of family/work conflict (strain-based) and family/work conflict (behaviour-based) based on age of the respondents $(p>0.05)$. However, the mean scores showed that the mean scores of family/work conflict (time-based) differed significantly based on level of education $(F=2.716, \mathrm{p}=0.046)$ with respondents Secondary school education level having significantly higher mean scores $(M=10.84)$ than respondents with Bachelors degree $(M=9.00)$. Further, the analysis showed that the mean scores of organisational commitment differed on the basis of education $(F=5.780, p=0.001)$. Respondents with College certificate 
$(\mathrm{M}=61.25)$ and Secondary school education $(\mathrm{M}=56.19)$ had significantly higher mean scores than respondents with Diploma $(M=49.40)$ and Bachelors degree $(M=51.12)$. It is possible that Police officers with higher levels of education were discontented due to unfulfilled career growth aspirations unlike police officers with lower levels of education who have uncompetitive skills in the job market.

e) Tenure

Table 6: Results of ANOVA exploring differences in family/work conflict and organisational commitment based on tenure

\begin{tabular}{|c|c|c|c|c|c|c|}
\hline & & $\mathrm{N}$ & Mean & $\begin{array}{l}\text { Std. } \\
\text { Deviation }\end{array}$ & & \\
\hline $\begin{array}{l}\text { Family/Work conflict } \\
\text { (Time based) }\end{array}$ & $\begin{array}{l}\text { Below } 5 \text { years } \\
6-10 \text { years } \\
11-20 \text { years } \\
21 \text { years and } \\
\text { above }\end{array}$ & $\begin{array}{l}34 \\
69 \\
43 \\
24\end{array}$ & $\begin{array}{l}10.12 \\
10.68 \\
9.91 \\
10.04\end{array}$ & $\begin{array}{l}3.09 \\
3.39 \\
3.91 \\
2.90\end{array}$ & .553 & .647 \\
\hline $\begin{array}{l}\text { Family/work conflict } \\
\text { (Strain based) }\end{array}$ & $\begin{array}{l}\text { Below } 5 \text { years } \\
6-10 \text { years } \\
11-20 \text { years } \\
21 \text { years and } \\
\text { above }\end{array}$ & $\begin{array}{l}34 \\
69 \\
43 \\
24\end{array}$ & $\begin{array}{l}11.74 \\
14.72 \\
13.58 \\
11.79\end{array}$ & $\begin{array}{l}3.89 \\
4.07 \\
5.25 \\
3.18\end{array}$ & 5.115 & .002 \\
\hline $\begin{array}{l}\text { Family/work conflict } \\
\text { (Behaviour based) }\end{array}$ & $\begin{array}{l}\text { Below } 5 \text { years } \\
6-10 \text { years } \\
11-20 \text { years } \\
21 \text { years and } \\
\text { above }\end{array}$ & $\begin{array}{l}34 \\
69 \\
43 \\
24\end{array}$ & $\begin{array}{l}17.29 \\
17.84 \\
17.19 \\
17.25\end{array}$ & $\begin{array}{l}3.20 \\
4.32 \\
3.70 \\
4.12\end{array}$ & .325 & .807 \\
\hline $\begin{array}{l}\text { Organisational } \\
\text { commitment }\end{array}$ & $\begin{array}{l}\text { Below } 5 \text { years } \\
6-10 \text { years } \\
11-20 \text { years } \\
21 \text { years and } \\
\text { above }\end{array}$ & $\begin{array}{l}34 \\
69 \\
43 \\
24\end{array}$ & $\begin{array}{l}54.79 \\
56.96 \\
53.81 \\
53.50\end{array}$ & $\begin{array}{l}8.53 \\
12.51 \\
9.11 \\
12.22\end{array}$ & 1.026 & .383 \\
\hline
\end{tabular}

The results in Table 6 show that there were no statistically significant differences in the mean scores of family/work conflict (time-based and behaviour-based) and organisational commitment based on tenure in the Police service $(p>0.05)$. However, the analysis showed that the mean scores of family/work conflict (strain-based) differed significantly based on years worked in the Police service $(F=5.115, \mathrm{p}=0.002)$ with respondents who have worked in the Police service for $6-10$ years $(M=14.72)$ having significantly higher mean scores than those who have worked for less than 5 years $(M=11.74)$ and those who have worked for 21 years and above $(M=11.79)$. It is possible that Police officers who have worked between $6-10$ years have young families which puts a lot of demands on the police officers while those who have worked for less than 5 years may be single while those who have worked for 21 years and above may have grown up children thus demands and responsibilities may be fewer.

f) Number of hours worked

Table 7: Results of ANOVA exploring differences in family/work conflict and organisational commitment based on age respondents

\begin{tabular}{|c|c|c|c|c|c|c|c|}
\hline & & & $\mathrm{N}$ & Mean & $\begin{array}{l}\text { Std. } \\
\text { Deviation }\end{array}$ & & \\
\hline \multirow{3}{*}{$\begin{array}{l}\text { Family/Work } \\
\text { (Time based) }\end{array}$} & conflict & 8 hours & 27 & 9.41 & 3.78 & \multirow[t]{3}{*}{2.690} & \multirow[t]{3}{*}{.071} \\
\hline & & $9-13$ years & 76 & 9.97 & 2.86 & & \\
\hline & & $\begin{array}{l}14 \text { hours and } \\
\text { above }\end{array}$ & 67 & 10.99 & 3.71 & & \\
\hline Family/work & conflict & 8 hours & 27 & 10.74 & 3.23 & 22.974 & .000 \\
\hline
\end{tabular}




\begin{tabular}{|ll|l|l|l|l|l|} 
(Strain based) & $\begin{array}{l}9-13 \text { years } \\
14 \text { hours and } \\
\text { above }\end{array}$ & 67 & 15.88 & 4.46 & & \\
& $\begin{array}{l}\text { conflict } \\
8 \text { hours } \\
9-13 \text { years } \\
\text { (Behavily/work based) }\end{array}$ & 27 & 16.96 & 3.35 & 5.017 & .008 \\
& $\begin{array}{l}14 \text { hours and } \\
\text { above }\end{array}$ & 67 & 16.66 & 4.16 & 3.65 & \\
& $\begin{array}{l}8 \text { hours } \\
9-13 \text { years }\end{array}$ & 27 & 54.96 & 8.94 & .635 & .531 \\
$\begin{array}{l}\text { Organisational } \\
\text { commitment }\end{array}$ & $\begin{array}{l}14 \text { hours and } \\
\text { above }\end{array}$ & 67 & 56.33 & 7.97 & & \\
\end{tabular}

The results in Table 7 show that there were no statistically significant differences in the mean scores family/work conflict (time-based) and organisational commitment based daily number of house worked ( $p>$ 0.05). However, the analysis showed that the mean scores of family/work conflict (strain-based) differed significantly based on daily number of hours worked $(F=22.974, \mathrm{p}=0.000)$ with respondents who work for 14 hours and above daily $(\mathrm{M}=15.88)$ having significantly higher mean scores than those who work for 8 hours $(\mathrm{M}=10.74)$ and those who work for $9-13$ hours $(\mathrm{M}=12.21)$. Further, respondents who work for 14 hours and above daily have higher mean scores $(F=5.017, \mathrm{p}=0.008, \mathrm{M} 18.63)$ for family/work conflict (behaviour-based) than respondents who work for 8 hours $(\mathrm{M}=16.96)$ and those who work for 9 - 13 years $(\mathrm{M}=16.66)$. It is possible that Police officers who work for 14 hours and above experience a lot of stress and challenges due to long absence from their families and are also more likely to exhibit aggressive behaviour towards their families as compared to Police officers who work between 8 to 13 hours.

\section{Results of Pearson Correlation analysis}

Hypotheses Two to Four sought to determine the effect of family/work conflict on organisational commitment of Police officers in Nakuru County, Kenya. These hypotheses were tested using Pearson's Correlation analysis which determines the strength and direction of the relationships.

Table 8: Pearson's Correlation analysis exploring the relationship between family/work conflict and organisational commitment

\begin{tabular}{|c|c|c|c|c|c|}
\hline & & $\begin{array}{l}\text { Family/wor } \\
\mathrm{k} \quad \text { conflict } \\
\text { (Time } \\
\text { based) }\end{array}$ & $\begin{array}{l}\text { Family/work } \\
\text { conflict } \\
\text { (Strain } \\
\text { based) }\end{array}$ & $\begin{array}{l}\text { Family/work } \\
\text { conflict } \\
\text { (Behaviour) }\end{array}$ & $\begin{array}{l}\text { Organisatio } \\
\text { nal } \\
\text { commitment }\end{array}$ \\
\hline $\begin{array}{l}\text { Family/work } \\
\text { conflict } \\
\text { based) }\end{array}$ & $\begin{array}{l}\text { Pearson } \\
\text { Correlation } \\
\text { Sig. (2-tailed) } \\
\mathrm{N}\end{array}$ & 170 & $\begin{array}{l}.390^{* *} \\
.000 \\
170\end{array}$ & $\begin{array}{l}.184^{*} \\
.016 \\
170\end{array}$ & $\begin{array}{l}-.023 \\
.764 \\
170\end{array}$ \\
\hline $\begin{array}{l}\text { Family/work } \\
\text { conflict } \\
\text { based) }\end{array}$ & $\begin{array}{l}\text { Pearson } \\
\text { Correlation } \\
\text { Sig. (2-tailed) } \\
\mathrm{N}\end{array}$ & $\begin{array}{l}.390^{* * *} \\
.000 \\
170\end{array}$ & 170 & $\begin{array}{l}.387^{* * *} \\
.000 \\
170\end{array}$ & $\begin{array}{l}-.047 \\
.539 \\
170\end{array}$ \\
\hline $\begin{array}{l}\text { Family/work } \\
\text { conflict (Behaviour) }\end{array}$ & $\begin{array}{l}\text { Pearson } \\
\text { Correlation } \\
\text { Sig. (2-tailed) } \\
\mathrm{N} \\
\end{array}$ & $\begin{array}{l}.184^{*} \\
.016 \\
170 \\
\end{array}$ & $\begin{array}{l}.387^{* *} \\
.000 \\
170 \\
\end{array}$ & $\begin{array}{l}1 \\
170 \\
\end{array}$ & $\begin{array}{l}-.268^{* * *} \\
.000 \\
170 \\
\end{array}$ \\
\hline $\begin{array}{l}\text { Organisational } \\
\text { commitment }\end{array}$ & $\begin{array}{l}\text { Pearson } \\
\text { Correlation } \\
\text { Sig. (2-tailed) }\end{array}$ & $\begin{array}{l}-.023 \\
.764\end{array}$ & $\begin{array}{l}-.047 \\
.539\end{array}$ & $\begin{array}{l}-.268^{* * *} \\
.000\end{array}$ & 1 \\
\hline
\end{tabular}




$\mid \mathrm{N}$
$\begin{aligned} & \text { **. Correlation is significant at the } 0.01 \text { level (2-tailed); *. Correlation is significant at the } 0.05 \\ & \text { level (2-tailed) }\end{aligned}$

\section{$\mathbf{H}_{0}$ 2: Family/work conflict (time-based) does not have statistically significant effect on organisational commitment of Police officers at Nakuru County}

The results in Table 8 showed that there was a weak insignificant correlation between family/work conflict (time-based) and organisational commitment $(r=-0.023, p>0.05)$. This suggests that family/work conflict (time-based) did not influence organisational commitment of Police officers.

\section{$\mathrm{H}_{0}$ 3: Family/work conflict (strain-based) does not have statistically significant effect on organisational commitment of Police officers at Nakuru County}

The results in Table 8 showed that there was a weak insignificant correlation between family/work conflict (strain-based) and organisational commitment $(r=-0.047, p>0.05)$. This suggests that strain-based family/work conflict did not influence organisational commitment of Police officers.

$H_{0}$ 4: Family/work conflict (behaviour-based) does not have statistically significant effect on organisational commitment of Police officers at Nakuru County

The results in Table 8 showed that there was a weak significant correlation between family/work conflict (behaviour-based) and organisational commitment $(r=-0.268, p<0.05)$. This suggests that organisational commitment declined when Police officers experienced behaviour-based family/work conflict. It is possible that Police officers experience stress due to conflict from behaviours at home where they are expected to be caring and emotional and behaviours at work where they are expected to be aggressive and commanding resulting in low organisational commitment.

\section{Results of multiple regression analysis}

$\mathrm{H}_{0} 5$ : The combined effect of employee personal characteristics and family/work conflict (time-based, strain-based and behaviour-based) do not have statistically significant effect on organisational commitment among Police officers at Nakuru County.

Hypothesis Four was tested using multiple regression analysis. Testing for multicollinearity was carried using variance inflation factor (VIF). Studies have shown that VIF value that is above 10 is a sign of multicollinearity while tolerance below 0.1 should be a cause for concern (Pallant, 2005; Field, 2009). In this study, VIF was below 2.8 while tolerance was above 0.3 which ruled out multicollinearity.

Table 9: Results of multiple regression analysis establishing the combined effects of personal characteristics, family/work conflict and organisational commitment

\begin{tabular}{|c|c|c|c|c|c|c|c|}
\hline & \multicolumn{2}{|c|}{$\begin{array}{l}\text { Unstandardized } \\
\text { Coefficients }\end{array}$} & \multirow{2}{*}{$\begin{array}{l}\text { Standardized } \\
\text { Coefficients } \\
\text { Beta } \\
\end{array}$} & \multirow[b]{2}{*}{$\mathrm{t}$} & \multirow[b]{2}{*}{ Sig. } & \multicolumn{2}{|c|}{$\begin{array}{l}\text { Collinearity } \\
\text { Statistics }\end{array}$} \\
\hline & B & $\begin{array}{l}\text { Std. } \\
\text { Error }\end{array}$ & & & & Tolerance & VIF \\
\hline (Constant) & 51.205 & 8.815 & & 5.809 & .000 & & \\
\hline Gender & .525 & 2.033 & .022 & .258 & .797 & .745 & 1.342 \\
\hline Marital Status & 4.511 & 2.186 & .163 & 2.063 & .041 & .846 & 1.182 \\
\hline Age & .469 & 1.538 & .037 & .305 & .761 & .360 & 2.775 \\
\hline $\begin{array}{l}\text { Level of } \\
\text { education }\end{array}$ & -2.080 & .755 & -.215 & -2.755 & .007 & .866 & 1.154 \\
\hline $\begin{array}{l}\text { Tenure in the } \\
\text { Police service }\end{array}$ & -2.025 & 1.346 & -.176 & -1.505 & .134 & .386 & 2.592 \\
\hline
\end{tabular}




\begin{tabular}{|c|c|c|c|c|c|c|c|}
\hline $\begin{array}{l}\text { Number of hours } \\
\text { worked daily }\end{array}$ & 1.486 & 1.303 & .096 & 1.141 & .256 & .749 & 1.336 \\
\hline $\begin{array}{l}\text { Family/work } \\
\text { conflict (Time } \\
\text { based) }\end{array}$ & .246 & .268 & .076 & .918 & .360 & .767 & 1.304 \\
\hline $\begin{array}{l}\text { Family/work } \\
\text { conflict (Strain } \\
\text { based) }\end{array}$ & .285 & .246 & .115 & 1.157 & .249 & .539 & 1.856 \\
\hline $\begin{array}{l}\text { Family/work } \\
\text { conflict } \\
\text { (Behaviour) }\end{array}$ & -.822 & .224 & -.293 & -3.678 & .000 & .831 & 1.204 \\
\hline
\end{tabular}

a. Dependent Variable: Organisational commitment

\section{Model Summary}

\begin{tabular}{|l|l|l|l|l|l|}
\hline Model & R & R Square & Adjusted R Square & $F$ (ANOVA) & Sig. \\
\hline 1 & $.393^{\mathrm{a}}$ & .154 & .107 & 3.248 & 0.001 \\
\hline
\end{tabular}

a. Predictors: (Constant), Family/work conflict (Behaviour), Marital Status, Level of education, Number of hours worked daily, Tenure in the Police service, Family/work conflict (Time based), Gender, Family/work conflict (Strain based), Age

The model summary of the regression analysis in Table 9 shows that personal characteristics and family/work conflict accounted for $15.4 \%$ of the variance in organisational commitment among Police officers in Nakuru County $(\mathrm{R}$ square $=0.154)$. This shows that $84.6 \%$ of the variance in organisational commitment was explained by factors not in the study. The standardized beta coefficients indicate that marital status $(\beta=0.163, p=0.041)$, level of education $(\beta=-0.215, \quad p=0.007)$ and behaviour-based family/work conflict $(\beta=-0.293, \mathrm{p}=0.000)$ were the only significant predictors of organisational commitment.

\section{Discussion}

The study was carried out among 170 Police officers in Nakuru County with an aim of determining the effect of personal characteristics and family/work conflict on organisational Commitment. The level of conflict that employees perceive between their working and personal lives on organizational commitment was centered on employee personal characteristics namely: gender, marital status, age, level of education, tenure and number of hours worked among the police officers. The study suggested that here are no significant differences in family/work conflict and organisational commitment focussed on employee personal characteristics namely: gender, marital status, age, education, tenure and number of hours worked. The report suggested that the biographical personal characteristics suggested that those who participated in the study were more male officers than the female gender the percentage. However, the results showed that more female police officers experienced more stress than men which spill into their work due to the multiple roles they play as wives, mothers, care givers, family career as well as employees. On marital status the of police officers who do not occupy the role of a spouse or parent do not experience real WFC as compared to the single parents who experience more conflict. These shows that the level of education, tenure of service and numbers of hours worked per day on how they influence organizational commitment among the police officers in Nakuru County, Kenya.

\section{References}

[1] Allen, T. D., \& Armstrong, J. (2006). Further examination of the link between work-family conflict and physical health: The role of health-related behaviours. American Behavioural Science, 49, $1204-$ 1221.

[2] Allen, N.J. \& Meyer, J.P. (1990). The Measurement and Antecedents of Affective, Continuance and Normative Commitment to the Organization. Journal of Occupational Psychology, 63, 1-18

[3] Allen, N.J. \& Meyer, J.P. (1997). Commitment in the Workplace: Theory, Research, and Application. Thousand Oaks, CA: Sage Publications. 
[4] Bashir, Sajid \& Ramay, I. M. (2008). Determinants of Organizational Commitment: A study of Information Technology Professionals in Pakistan. Journal of Institute of Behavioural \& Applied Management.

[5] Boxall, P., Ang, H.S. \& Bartram, T. (2011). Analysing the Black box of HRM: uncovering HR goals, mediators and outcomes in a standardized service environment. Journal of Management Studies, pp. $1504-1532$.

[6] Carlson, D.S., Kacmar, K.M. \& and Williams, L. J. (2000). Construction and initial validation of a multidimensional measure of work-family conflict. Journal of Vocational Behaviours. 56:249-76.

[7] Cohen, D. B. (2003). Where Did that Child Come from? Why Some of Our Children Turn-Out So Different From Us and What the Answers Reveal About our Parenting and Ourselves. Templegate.

[8] Duxbury, L. \& Higgins, C. (2003). Work Life Balance: In The New Millennium: Where are we? Where we need to go? CPNR Discussion papers no W/12October. Human Resource Management. 39, 17-32.

[9] Edwards, J. R \& Rothband, N, P. (2002). Mechanisms Linking Work and Family: Clarifying the Relationship between Work and Family Construct. The Academy of Management Review, vol.25, No 1, pp178

[10] Greenhaus, J. H., \& Beutell, N. J. (1985). Sources of Conflict between Work and Family Roles. Academy of Management Review, 10, 76-88.

[11] Frone, M. R., Russell, M. \& Cooper, M. J. (1997). Relation of Work-Family Conflict to Health Outcomes: A Four-Year Longitudinal Study of Employed Parents. Journal of Occupational and Organizational Psychology, 70, 325-336.

[12] Higgins, C., Duxbury, L. \& Johnson, K. L. (2000). Part-Time Work For Women: Does It Really Help Balance Work And Family? Human Resource Management.

[13] Kahn, R., Wolfe, D., Quinn, R., Snoek, J. \& Rosenthal, R. (1964). Organizational Stress: Studies on Role Conflict and Ambiguity. New York: Wiley.

[14] Kopelman, R. E., Greenhaus, J. H. \& Connolly, T. F. (1983). A model of work, family, and interrole conflict: A construct validation study. Organizational, Behaviour, and Human Performance, 32, 198215.

[15] Kossek, E. (2016). Implementing Organizational work-life interventions: Towards a triple bottom line. Community Work and Family, 19 (2), 242-256

[16] Lockwood, N. R. (2003). Work/Life Balance: Challenges and Solution. 2003 Quarterly Report” HR Magazine June.

[17] Netemeyer, R.G., Boles, J.S. \& McMurrian, R. (1996). Development and Validation of Work family Conflict and Family-Work Conflict Scales. Journal of Applied Psychology. 81 (4): 400-410.

[18] McClean, E. \& Collins, C.J. (2011). 'High commitment HR practices, employee effort and firm performance: investigating the effects of HR practices across employee groups within professional services firms', Human Resource Management, 50(3), pp. 341 - 363 (online Wiley).

[19] Mugenda, O.M., \& Mugenda, A.G., (2003). Research Methods: Quantitative \& Qualitative Approaches: Nairobi Act Press.

[20] Omeja, K \& Githigaro, J. K (2010). The challenges of State Policing in Kenya, The Peace and Conflict Review Journal, 7 (1), pp. 1-31

[21] Ongoro, B. O. \& Oloko, M. (2015). Effects of Stress on Job Performance among Police Officers: A Case of Migori County, Kenya, the International Journal of Business \& Management, 3 (4), pp. 286304

[22] Oweke, J. A., Muola, J., \& Ngumi, O (2014). Causes of Occupational Stress In Relation To Level of Occupational Stress among Police Constables in Kisumu County, Kenya. Journal of Psychology and Health, 15,163-17.1.

[23] Pallant, J. (2005). SPSS survival manual: a step by step guide to data analysis using SPSS for

a. Windows (Version 12), 2nd edn. Maidenhead: Open University Press.

[24] Saunders, Thornhill \& Lewis (2009). Research Methods for Business Students, 5th Edition, Prentice. Hall, p.130.

[25] Sutton, M. (2000). Interpreting Cross Sectional Data on Stages of Change. Psychology and Health. 